\title{
Henry VIII, McLeod syndrome and Jacquetta's curse
}

\author{
${ }^{1} \mathrm{P}$ Stride, ${ }^{2} \mathrm{~K}$ Lopes Floro \\ ${ }^{1}$ Consultant Physician and Senior Lecturer; ${ }^{2}$ GMC4 student, University of Queensland School of Medicine, Brisbane, Australia
}

\begin{abstract}
The mental decline of King HenryVIII from being a jovial, charismatic and athletic young man into an increasingly paranoid, brutal tyrant in later life, ever more concerned at his lack of one or more male heirs, has attracted many medical diagnostic theories. Previous hypotheses have included diabetes, syphilis and hypothyroidism, among others. However, these inadequately explain Henry's failure to produce a male heir, despite multiple pairings. The latest postulated diagnoses for Henry are the coexistence of both Kell blood group antigenicity (possibly inherited from Jacquetta Woodville, Henry's maternal great grandmother) causing related impaired fertility, and McLeod syndrome, causing psychotic changes. As the mutated McLeod protein of the syndrome significantly reduces the expression, effectively inactivating the Kell antigen, we critically review this theory, examining in detail the pathophysiology of these conditions and assessing the genealogy of Henry VIII and its effect in subsequent generations.
\end{abstract}

\author{
Correspondence to $\boldsymbol{P}$ Stride \\ 23 Aland St \\ Wavell Heights \\ Brisbane, Queensland \\ Australia \\ tel. 04 I 7039 III \\ e-mail pjostride@gmail.com
}

KEYWORDS Henry VIII, Kell antigen, McLeod syndrome, Jaquetta St Pol, infertility, psychosis

DECLARATIONS OF INTERESTS No conflicts of interest declared.

\section{INTRODUCTION}

Explanation of the decline of Henry VIII from a jovial, athletic, popular young 'bluff King Hal' into a paranoid, tyrannical and ailing old man struggling to produce a male heir has attracted many medical hypotheses, including syphilis and diabetes. We explore in detail the recent suggestion by Whitley and Kramer' that Henry's infertility was caused by Kell antigen and his psychosis by the associated McLeod syndrome (MLS), a progressive neurological disorder characterised by behavioural changes, late-onset dementia, peripheral neuropathy and haemolytic anaemia.

\section{HENRY VIII}

Henry VIII was descended from a traditional English heritage (Figure I). His ancestors included Yorkist nobility, minor English and Welsh knights, the illegitimate Lancastrian offspring of the mistress of John of Gaunt, and the European aristocratic connections of Jacquetta St Pol and Catherine de Valois. Genetic problems have been proposed as an explanation for his psychiatric and reproductive problems. Two of his great grandmothers (St Pol and de Valois) are the geneticist's focus and will be discussed further.

Henry VIII as a young man appeared to be an ideal king; he was pleasant, jovial, gregarious and athletic (Figure 2A). He delighted in sports, particularly jousting and martial arts. He wanted to fight in battle and become a military hero like his grandfather, Edward IV. Henry was also an intellectual, interested in theology, music and literary arts. He enjoyed the company of women and excelled on the dance floor. However, before his fortieth birthday, he began to undergo a personality change, becoming one of the worst of English monarchs, a paranoid, egotistical and brutal tyrant. ${ }^{1,2}$ There were many executions during his reign, particularly in the later years. The more fortunate victims were beheaded with a single stroke, the less fortunate by several strokes, sometimes preceded by the horrendous ritual of being hung, castrated and eviscerated. The numbers are uncertain and will probably never be known but Holinshed, ${ }^{3}$ in his chronicles written only 40 years after Henry's death estimated the number at 72,000 , or 2,000 per year during his reign. This amounts to approximately $3.5 \%$ of the population of England, estimated at 2.1 million in $1541,{ }^{4}$ or $0.1 \%$ per year. He executed the rich and poor, male and female alike, whereas previous monarchs had usually spared women. He executed his current wives, nobles with better claims to the throne than his, political advisers for whom he had no further time and religious adversaries. Putting that in modern perspective, the best estimate of the current rate of current global executions from Amnesty International is about 4,000-5,000 per year. ${ }^{5}$ If Henry's execution rate of $0.1 \%$ per year was applied globally today, there would be seven million executions annually. 


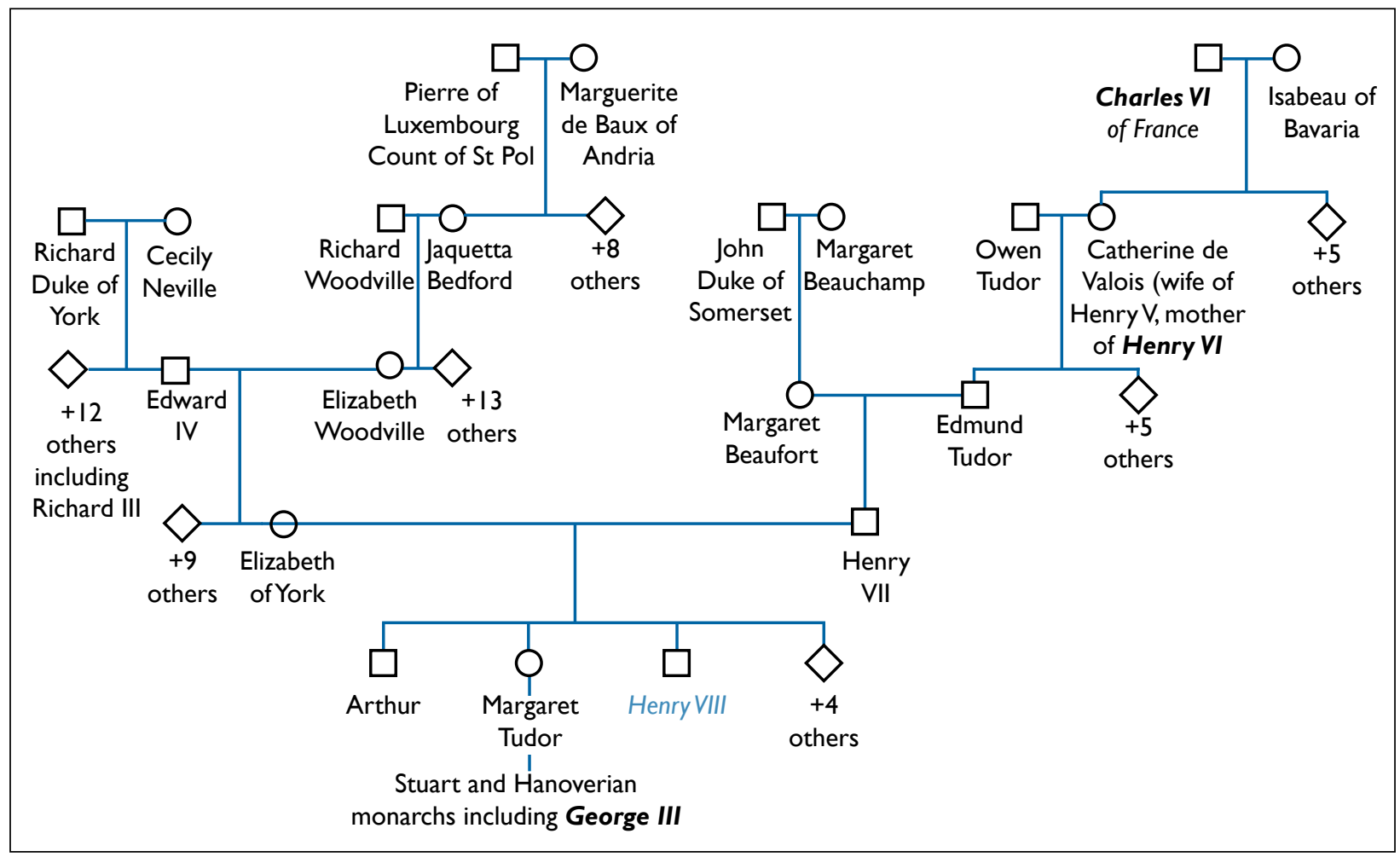

FIGURE I King Henry VIII's family tree. King Henry VIII is highlighted with blue text. Previous kings with psychiatric problems are in bold italics. To simplify the family tree only pairings which contributed genetically to King Henry VIII are shown, other marriages and divorces are not. A number of family members have been grouped together. Males: squares; Females: circles. Multiple family members of the one generation: diamonds.

\section{MEDICAL DIAGNOSES}

\section{Diabetes}

In later life, Henry became morbidly obese (Figure 2B), weighing an estimated 28 stone at the time of his death. ${ }^{6}$ His waist circumference, based on the size of his sequential suits of armour, increased by 20 inches to 54 inches over 27 years, ${ }^{7,8}$ and he was moved around with mechanical devices. He also had a painful ulcerated malodorous lesion on his leg, perhaps an old jousting injury which had reopened. Diabetes is commonly suggested as the cause of his poor healing, and may have also been present in Edward IV, his maternal grandfather. ${ }^{9}$ Less likely is the possibility that Cushing's syndrome was responsible for his obesity, diabetes and poor wound healing. Unfortunately neither obesity nor diabetes could explain Henry's earlier reproductive problems.'

\section{Syphilis}

Another commonly suggested disease from which Henry may have suffered is syphilis. Medical historians debate whether this disease was present in Europe in the pre-Columbian era, a controversy beyond the scope of this paper. However this infectious disease spread rapidly across Europe like a new condition, or at least a new mutation of an existing disease in a 'virgin soil', at the end of the fifteenth century, ${ }^{8}$ possibly introduced into Europe from the Americas by Christopher Columbus's crews, and perhaps introduced into Scotland by Perkin Warbeck's mercenary army. ${ }^{10}$ Indeed it would be ironic if Warbeck, who aimed to displace Henry VII, was indirectly responsible for Henry VIIl's final illness. However the total absence of evidence of congenital syphilis in his legitimate and illegitimate children ${ }^{7.8}$ or reports of syphilis in Henry's many sexual partners is considered to make this diagnosis improbable.

\section{Head injury}

Henry suffered a head injury while jousting in 1536, following which he was either aphasic or unconscious for two hours, ${ }^{8}$ an event concurrent with his increasing tyranny. A few days later Anne Boleyn had a miscarriage, perhaps as a result of this incident, initiating the events that led to her beheading. Frontal lobe damage causing what is now known as post-traumatic stress disorder and a personality change, or pituitary damage causing growth hormone deficiency and subsequent obesity have also been hypothesised to explain the changes in Henry's personality and behaviour. ${ }^{7}$

\section{HENRY VIII AND GENETICS}

Whitley and Kramer' have recently postulated a genetic defect to explain both Henry's failure to produce many children, and the personality and cognitive defects he 

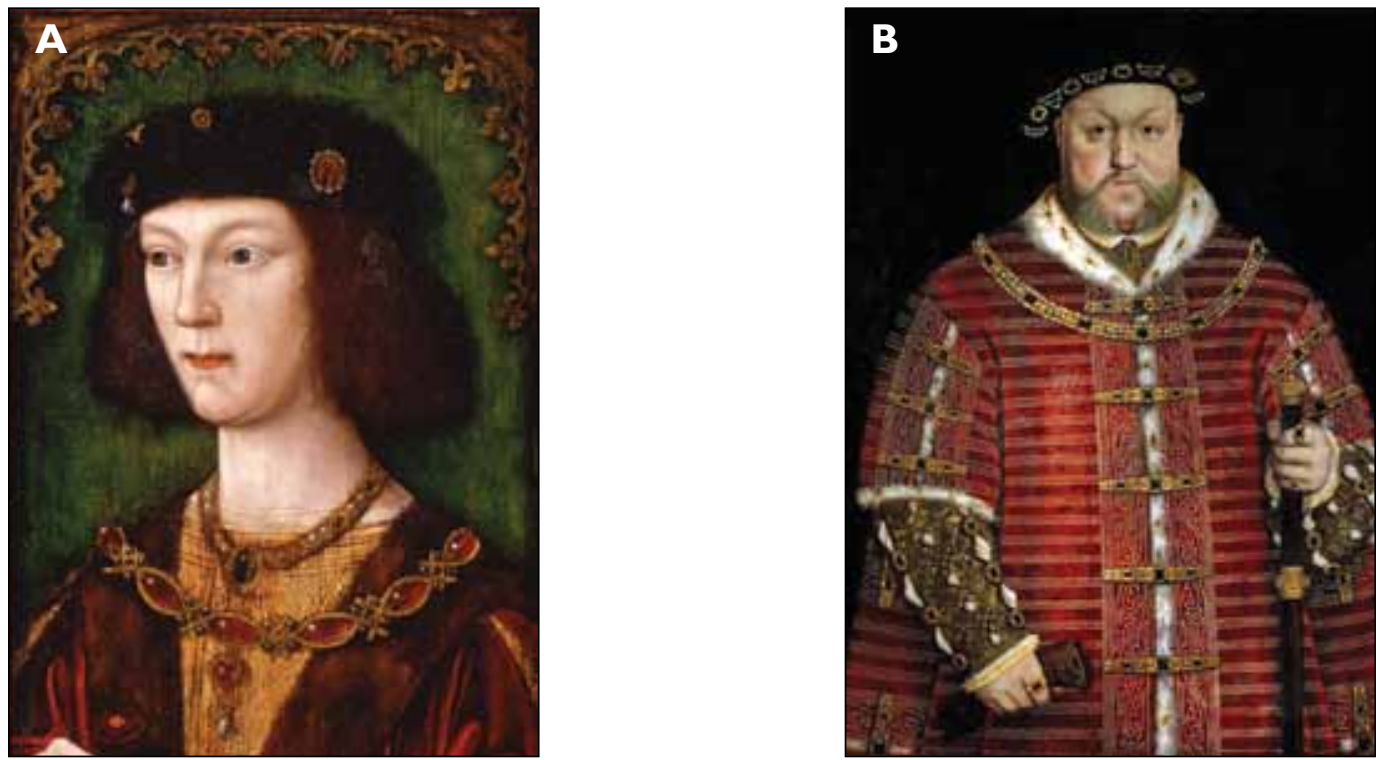

FIGURE 2 King Henry VIII, the King of Mystery. (A) Portrait of Henry VIII at I8 years by an unknown painter. British School, Henry VIII, c. I509. Berger Collection at the Denver Art Museum. Photograph kindly provided by the Denver Art Museum. (B) Portrait (1542). From the Castle Howard Collection. Reproduced by kind permission of the Hon. Simon Howard. This portrait was painted approximately 33 years later and depicts a Henry VIII as a monarch with increasing obesity, considerable ageing and a less certain, potentially childlike quality.

developed in middle age. They suggest the coexistence of both Kell blood group antigenicity (possibly inherited from Jacquetta Woodville, Henry's maternal great grandmother) causing related impaired fertility and MLS, causing psychotic changes.

\section{KELL IMMUNOGENICITY}

The Kell blood group system is similar in principle to the better known $\mathrm{ABO}$ blood types and the Rhesus system $(\mathrm{Rh})$, as a major erythrocyte antigen. The Kell antigens are proteins found mainly on the surface of erythrocytes, though they are also found in myeloid cells, lymphoid tissue, muscle and the nervous system. The Kell locus, located on chromosome seven, is highly polymorphic with approximately $3 \mathrm{I}$ alleles. The two main co-dominant alleles are $\mathrm{K}$ and $\mathrm{k}$ (alternatively described as $\mathrm{KI}$ and $\mathrm{K} 2$ ).

The $\mathrm{K}$ allele is an immunogen which can generate red cell antibodies leading to haemolytic disease of the newborn or a transfusion reaction to incompatible blood, while $\mathrm{k}$ does not cause clinically significant immunological reactions. The phenotype frequencies in Caucasians are $\mathrm{K} / \mathrm{K} 0.2 \%, \mathrm{~K} / \mathrm{k} 8.8 \%$ and $\mathrm{k} / \mathrm{k} 91 \%$; i.e. heterozygosity for the $\mathrm{K}$ allele is much more common than homozygosity." Henry, if carrying the Kell positive gene, is therefore statistically much more likely to be heterozygous, and of course it is essential for the Whitley and Kramer hypothesis that he must be heterozygous to produce a child, Mary, without haemolytic disease.
Genetic incompatibility between a male and female can cause spontaneous abortion, other intrauterine disease and death in their offspring. A Kell antigen negative female fertilised by a Kell K positive male may develop antibodies against a second or subsequent fetus's red cells resulting in alloimmunisation and subsequent haemolysis and possible miscarriage, stillbirth or early neonatal death (Table I)." However Kell antigenaemia has also been reported in primagravid women. ${ }^{12-14}$ This occurrence can be caused by previous blood transfusion from a Kell positive donor, obviously not a factor in Tudor England, or by an antepartum feto-maternal haemorrhage, either spontaneous or traumatic, such as in a fall in late pregnancy, resulting in fetal bleeding and mixing of fetal and maternal circulation with alloimmunization. ${ }^{12}$

Van Wamelen also discusses the severity of this problem. Kell-related haemolytic disease of the fetus and newborn (HDFN) is the second major cause of HDFN after Rhesus-D (Rh-D) alloimmunisation, with an incidence of 3.2 in I,000. Severe cases of HDFN requiring intrauterine blood transfusion have a mortality rate of $42 \%$ compared with II\% of similar cases in Rh-D related HDFN. ${ }^{14}$

Any family possessing the $\mathrm{K}$ antigen would be expected to have a family tree in which the male line would have increased perinatal mortality. Fifty per cent of the subsequent children would be at risk from the mother's immune system in the case of a heterozygous Kell antigen positive male pairing with a $\mathrm{k} / \mathrm{k}$ mother. 


\begin{tabular}{|c|c|c|c|l|}
\hline $\begin{array}{l}\text { Maternal Kell } \\
\text { phenotype }\end{array}$ & $\begin{array}{l}\text { Previous } \\
\text { pregnancy K } \\
\text { phenotype }\end{array}$ & $\begin{array}{l}\text { MLS } \\
\text { mutation } \\
\text { status in the } \\
\text { current fetus }\end{array}$ & $\begin{array}{l}\text { Current } \\
\text { pregnancy's } \\
\text { Kell } \\
\text { phenotype }\end{array}$ & Current pregnancy \\
\hline- & - & - & - & Unremarkable current pregnancy \\
\hline- & - & - & $\mathrm{K}$ & Maternal alloimunisation and potential morbidity \\
\hline- & $\mathrm{K}$ & - & - & $\begin{array}{l}\text { Unremarkable current pregnancy, but alloimmunised } \\
\text { from previous pregnancy }\end{array}$ \\
\hline- & $\mathrm{K}$ & - & $\mathrm{K}$ & $\begin{array}{l}\text { Morbidity, miscarriage, still birth, early neonatal death } \\
\text { or an unremarkable current pregnancy }\end{array}$ \\
\hline- & $\mathrm{K}$ & $\mathrm{MLS}$ & $\mathrm{K}$ & $\begin{array}{l}\text { Likely decreased potential for morbidity, miscarriage, } \\
\text { still birth and neonatal death. Especially if a male fetus. }\end{array}$ \\
\hline $\mathrm{K}$ & $\mathrm{K}$ or - & - & $\mathrm{K}$ & Unremarkable current pregnancy \\
\hline
\end{tabular}

TABLE I Kell alloimmunisation and the effect of a MLS mutation on the current pregnancy. Morbidity described in the above table includes hydrops fetalis, respiratory distress syndrome, hyperbilirubinemia, and a potential requirement for a blood transfusion. $\mathbf{K}=$ an individual with the immunogenic Kell antigen; $\mathbf{M L S}=$ an individual with a mutation in the gene responsible for McLeod syndrome; dash= an individual with the $\mathrm{k}$ Kell antigen or without a mutation in the gene responsible for McLeod syndrome

Jacquetta St Pol, maternal great grandmother of Henry VIII and the potential source for antigenicity

Jacquetta Woodville was born an aristocrat, married into a royal family, and is an ancestor of every subsequent English monarch. As the daughter of Pierre of Luxembourg (Count of St Pol) and Marguerite de Baux of Andria (cousin of Sigismund of Luxembourg, the reigning Holy Roman Emperor, and King of Bohemia and Hungary), she married John of Lancaster, first Duke of Bedford (the third son of King Henry IV of England and Mary de Bohun), and then Sir Richard Woodville. ${ }^{15} \mathrm{Her}$ first marriage was childless but she and Richard Woodville produced at least I 3 children, one of whom, Elizabeth, married King Edward IV. Edward and Elizabeth's firstborn child (Jacquetta's granddaughter), also Elizabeth (sister to King Edward V, niece of King Richard III) married Henry VII and gave birth to Henry VIII. Consequently Jacquetta is an ancestor to all subsequent English monarchs. Interestingly she was accused of witchcraft more than once. She was said to have bewitched Edward IV such that he fell passionately in love with Elizabeth Woodville at their first meeting, and impulsively married her in secret soon afterwards. ${ }^{16}$ The Earl of Warwick, during his brief ascendancy in 1469 , executed Jacquetta's husband and observed accusations made by two men that Jacquetta had used images to cast spells, including one used to bewitch Edward IV. ${ }^{17}$ These accusations were dropped when Edward regained his throne, but were revived by Richard III in the Titulus Regius Act alleging that Jacquetta procured Edward's marriage to Elizabeth though witchcraft. ${ }^{17}$ A modern understanding of medicine suggests that Jacquetta may have cursed Edward IV not by witchcraft but through genetics at the Kell locus.

\section{A likely maternal origin for Henry VIII's Kell status}

Edward IV had ten children with Elizabeth Woodville, and more children with other women, seven of whom survived him. Given the high perinatal mortality rate, this suggests that it is unlikely that the $\mathrm{K}$ antigen was present in either of Edward's parents. In support of this argument, Edward's father, Richard, the third Duke of York had at least 13 children. Clearly the Yorkist line was very fertile. Similarly Richard Woodville had 14 children with Jacquetta, suggesting that he was unlikely to be the source of the $\mathrm{K}$ antigen. However, if Jacquetta had been the source of the $K$ antigen, her daughters would have carried the allele, and therefore alloimmunisation and fertility problems could have been apparent in half of Edward IV's male children or in half of the male brothers of Henry VIII. Unfortunately, none of Edward's IV male children reached reproductive age and married. George Plantagenet died in early childhood and the remaining two children were the 'Princes in the Tower' whose fate remains unknown pending re-evaluation of 'their' bones. Henry's only brother died before producing a child, though perhaps not before sexual intercourse with Katherine of Aragon.

\section{An unlikely paternal origin for Henry VIII's Kell status}

A review of Henry VIII's paternal family tree demonstrates that Henry VII had seven children who survived to reach the ages of eight days, 16 months, three, I5, 37, 5I and 55. Alloimmunisation would be a highly improbable cause of death for a 16-month-old child. However the death of Katherine Tudor at eight days would be compatible with HND. However, given the high incidence of postnatal death in the era, and the fact that her mother, Elizabeth of York, died in childbirth suggest an alternative problem, and it is improbable that 
Henry VII was the source of the Kell antigen. As such Jacquetta is without doubt the most likely candidate for the source of the $\mathrm{K}$ antigen.

\section{Evidence in support of Jacquetta as the source of} the immunogenic Kell antigen

Given the above analysis, a study of Jacquetta's children ${ }^{16,18}$ is clearly relevant in establishing whether she could have been a carrier of the Kell positive gene. As previously noted, $\mathrm{K} / \mathrm{K}$ homozygosity is rare, and it is more probable that Jacquetta could have been a $\mathrm{K} / \mathrm{k}$ heterozygote, such that her offspring had a $50 \%$ of inheriting the immunogenic $\mathrm{K}$ allele. If this is correct we would expect to find that a review of her Kell positive male children would have not more than a single healthy child.

Lewis Woodville, the first son, born in 1438, appears from limited information to have died age 12 in 145 I without issue. Anthony Woodville, the second son, born in 1442, played a leading role in the events of the time; he was an excellent jouster, and fought in the battles of Towton and Barnet. Though twice married he never had any children. John Woodville, the third son, born in 1445 , was married to Catherine Neville, the Dowager Duchess of Norfolk, a marriage of political expediency perhaps to advance the power of the Woodville family. She was at least 65 years old, he was 19 or 20 , yet she outlived him, as John was executed in 1469. Unsurprisingly there were no children. Lionel Woodville, the fourth son, born in 1447, went into the church, becoming Bishop of Salisbury. There is no evidence of marriage or offspring, beyond improbable rumours that he fathered Stephen Gardiner, subsequent Bishop of Winchester. Lionel is recorded as being the first person to receive an honorary university degree, in this case from Oxford. Richard Woodville, the fifth son, officially did not marry, and had no children. Richard adopted a low profile and tried to avoid taking sides in the War of the Roses. There are unconfirmed rumours that he married secretly and had one son, who was raised under a different name to avoid the violent deaths of many of his relatives. Edward Woodville, the sixth son, born in 1455 , appears never to have married and had no known children. Thomas Woodville, the seventh son, is documented as marrying Ann Holland, but history does not record any offspring.

Thus of seven sons, four clearly had no children, and the other three had no documented offspring. Only Anthony and Thomas had documented marriages, but no children; Lewis died young; John married a postmenopausal woman; and Lionel, Richard and Edward never married. This does not confirm or refute Kell blood group positivity, but it supports the above deduction that Jacquetta was the most likely source of this condition if it is causative. As such, Jacquetta's genes may well have been the curse preventing Henry VIII's attempts to produce healthy male heirs.

\section{HENRY AND KELL BLOOD GROUPS}

Henry had multiple sexual partners, as well as six wives, though not all the marriages were consummated. There were a few known other partners, though the total numbers and identities, as was the case with many kings, cannot be accurately established. Collectively the partners appeared to have little problem becoming pregnant, most having one child, often from the first pregnancy, but subsequently had a series of miscarriages, stillbirths and neonatal deaths.

\section{Henry's wives}

The obstetric history of Katherine of Aragon, Henry VIII's first wife, is not supportive of Whitley's Kell antigen hypothesis in which only the initial pregnancy is successful. Katherine's first pregnancy produced a premature stillborn female, her second a son, Henry, who died when seven weeks old. After a possible miscarriage she produced a premature son in 1513 and a premature daughter in 1514 who both died shortly after birth. ${ }^{8}$ Mary, the only child who survived Katherine, was born of the fifth pregnancy in 1517. Katherine's final pregnancy produced a baby girl who died soon after birth. Thus Katherine was clearly fecund but only her fifth pregnancy produced a healthy child. Whitley and Kramer' rightly suggest that Mary may have inherited the recessive Kell negative gene from her father, while all Katherine's other fetuses inherited Kell positivity. Anne Boleyn, Henry's second wife, gave birth to Elizabeth I in 1533, but her two or three subsequent pregnancies ended in miscarriages or perhaps one stillbirth. Jane Seymour, the third wife, gave birth to Edward VI in her first pregnancy, but died 12 days later, perhaps with puerperal sepsis. ${ }^{8}$ Henry took an instant dislike to Anne of Cleves, his fourth wife, and their marriage was annulled, reportedly unconsummated. His last two wives had no recorded pregnancies. Bessie Blount, a royal mistress, gave birth to Henry Fitzroy in her first pregnancy, but had no more children with Henry. Mary Boleyn was the king's mistress and had two children, but the father is not clearly identified.

Thus Henry is known to have impregnated at least four women, producing at least II pregnancies. Three of his four surviving children were the product of that woman's first pregnancy, consistent with predictions assuming Kell incompatibility.

Given the above, Henry's reproductive problems could therefore be explained by him being heterozygous for the Kell antigen, possessing the $K$ and a non-immunogenic Ko or $\mathrm{k}$ alleles, and his sexual partners the more usual $\mathrm{k}$ allele. Katherine's only successful pregnancy, the fifth producing Mary, could be explained if the first four fetuses inherited Henry's K antigen (a one in 16 chance), while Mary, the fifth child, was the only child of Henry 
and Katherine's union to inherit a k gene from Henry. An alternative explanation for Katherine's problems is that Arthur, Prince of Wales, her first husband, was like Henry, Kell positive, and that not only did they consummate the marriage, but Katherine, at that time a naive 15-year-old, had an unrecognised brief pregnancy with an early miscarriage in which she became sensitised to the Kell antigen prior to her coupling with Henry. A third possibility is that Henry was not the father of Mary. Katherine would not have been the first woman to believe that her problems in pregnancy were not her fault and to seek an alternative sperm donor.

Lastly, as rightly pointed out by Whitley and Kramer, it should be realised that the rarity of the immunogenic $\mathrm{K}$ antigen better explains why so many of Henry's pairings with different women were unsuccessful. If Henry had been simply Rh-D positive then he would have expected to have more easily found a rhesus compatible wife and produced more viable offspring.

\section{HENRY AND MCLEOD SYNDROME}

The second part of Whitley and Kramer's hypothesis is the related concept of MLS. The McLeod gene is located on the $X$ chromosome and encodes the $X K$ protein. This protein is found on the surface of erythrocytes and covalently binds the Kell glycoproteins. In its absence, Kell antigens are only weakly expressed on the cell surface and thus are less likely to be recognised by the surveilling immune system. As such one can consider it necessary for the presentation of the Kell antigens. ${ }^{19}$

McLeod syndrome is a genetic disorder, first discovered in $196 \mathrm{I}$ in a dental student. It results from a variety of recessive mutations or deletions in the $\mathrm{XK}$ gene. Pathological features include psychoses, behavioural changes, dementia, seizures, movement disorders, peripheral neuropathy, muscular dystrophy, cardiomyopathy and haemolytic anaemia with acanthocytosis. Symptoms develop in midlife and commonly affect the nervous system, heart and blood vessels. Pathological changes include loss of neurones with atrophy and gliosis predominantly in the caudate and globus pallidus, and possibly in the thalamus, substantia nigra and putamen, with sparing of the cerebellum and cortex. In life these changes may be revealed by an increased T2 signal on magnetic resonance imaging $(\mathrm{MRI}){ }^{20}$

However, although Henry displayed significant behavioural change, he was not reported to have a neurological movement disorder such as epilepsy, and his chronic leg ulcer caused considerable pain, arguing against a sensory neuropathy. McLeod syndrome may also be associated with chronic granulomatous disease (CGD), ${ }^{21}$ but Henry is predominantly recorded as having only one chronic lesion, rather than the usual many chronic bacterial and fungal lesions of CGD. Multiple ulcers would be additional support for a diagnosis of CGD and MLS. Unfortunately, the presence of a cardiomyopathy or mild anaemia would have been difficult to detect with the medical knowledge of the period in a grossly obese man with one or more leg ulcers. However, he did suffer from immobility requiring a tramme, a chair with four poles attached.' Given this, it is debatable whether Henry displayed the MLS picture or not. Interestingly, Singleton ${ }^{22}$ reported a case of MLS who developed slight dementia and aggressive behaviour. Zeman ${ }^{23}$ described a case who developed cognitive impairment with copious inappropriate speech, disorganisation leading to loss of employment, inappropriate periods of nakedness and who physically abused his wife. While some of these descriptions accord with some of Henry's clinical features, the only feature of MLS that Henry undoubtedly did display was cognitive dysfunction with a tyrannical psychosis developing in later life.

\section{HENRY VIII, MCLEOD SYNDROME AND THE KELL ANTIGEN}

The hypothesis proposed by Whitley and Kramer is further complicated by the evidence that McLeod's mutations inactivate the antigenic potential of Kell proteins. ${ }^{24-26}$ If Henry had MLS, he would have an inactive Kell antigen. His children would inherit only a random segregation of his genotype and thus would not necessarily be protected from alloimmunisation against the immunogenic $\mathrm{K}$ allele, a process involving mother and fetus. Specifically, Henry's male children would not inherit his postulated X-linked McLeod mutation, so alloimmunisation could still occur if the male child inherits Henry's immunogenic $\mathrm{K}$ allele, and the mother is Kell negative.

In contrast, while Henry's daughters would inherit his McLeod mutated gene, together with a normal $X$ chromosome from their mothers, some may still have experienced negative immunogenic selection if they also co-inherited the immunogenic $\mathrm{K}$ antigen. Normally random $X$-inactivation occurs, such that some red blood cells (RBC) display the MLS haematological phenotype while others do not. ${ }^{27}$ As such, those RBCs which fail to express the MLS phenotype (i.e. silence the MLS mutant allele) are capable of displaying the immunogenic $\mathrm{K}$ allele. This point was overlooked in Whitely and Kramer's analysis, and it is important as it would explain why Henry was also lacking in viable female progeny.

There is however the possibility that during normal development random inactivation can become significant, skewed by chance. As such there is predominant inactivation of the wild type McLeod protein. Consequently these women would also suffer from MLS, and may have reduced maternal immune 
activation, allowing them to survive fetal life. In other women this situation could be reversed, with inactivation of the mutant McLeod carrying $\mathrm{X}$-chromosome and the subsequent development of HND. This is not a hypothetical concept. Total suppression of a wild type gene can result in an $X$-linked disease being expressed in a woman. Orstavik ${ }^{28}$ for example reported a case of $X$-linked haemophilia $B$ in a woman due to failed inactivation of defective $\mathrm{X}$-chromosome. Acanthocytosis has been reported in the mother of one case with MLS, ${ }^{29}$ and MLS has been reported in a woman due to a novel point mutation in the McLeod gene associated with marked skewing of $X$-inactivation, particularly in the blood and brain. ${ }^{30}$ Thus it is possible that MLS can present in women with skewed inactivation during fetal development and that they may or may not suffer Kell-related HDFN. Such females would be at risk of developing the neurological symptoms of MLS in later life. One might question whether Henry VIIl's daughter Mary I, also known as Bloody Mary, could epitomise this scenario.

Historical records do not support a diagnosis of MLS for Henry VIII nor for the other British monarchs. While the phenotypic likelihood of MLS in Henry VIII is debatable at best, do historical records support a genetic basis?

Psychiatric problems occurring in British and other European monarchs during the last millennium are well known. King Charles VI of France (1368-1422), his grandson, King Henry VI of England (142I-147I) and King George III of England suffered undisputed periods of insanity requiring regencies. ${ }^{16,31,32}$ Some authorities believe King George III suffered from porphyria ${ }^{31}$ and suggest that his ancestors Margaret Tudor (the sister of Henry VIII), Mary Queen of Scots and King James VI of Scotland also suffered from this condition. Yet this diagnosis is highly disputed; ${ }^{32-34}$ other postulated alternative diagnoses including arsenic toxicity and depression have been suggested for George III, ${ }^{31,32,34}$ and bipolar disorder or schizophrenia for Charles $\mathrm{VI}$ and Henry VI. ${ }^{35}$

Since Catherine de Valois (daughter of Charles VI of France), links all three as wife of Henry $V$, and subsequently, mother of Henry $\mathrm{VI}$, grandmother of Henry VII, great grandmother of Henry VIII, and a direct ancestor of George III, it is tempting to speculate that she carried and shared a partially penetrant genetic predisposition to mental illness. As such, Henry VIII may have inherited the same genetic predisposition to mental illness and hereditary insanity from her. Furthermore, the intermittent appearance in the subsequent English Royal family, suggests Henry VII passed this partially penetrant trait on to successive generations. Consistent with this, other members of the British Royal family throughout the last millennium have displayed characteristics reasonably described as eccentricities. However, given that MLS is X-linked, a cursory glance would suggest that it is an unlikely culprit responsible for the genetic predisposition for mental illness carried by Catherine de Valois. This is because King Henry VIII must have inherited his lone $X$ chromosome from his mother Elizabeth of York. It is unlikely that she also carried an X-linked mutation responsible for MLS. Furthermore, support for this comes from review of both her father, Edward IV, and maternal grandfather, Richard Woodville, who lived to the age of $4 \mathrm{I}$ and 64 , without evidence of mental disease. Both past the typical MLS presentation age of between 30 and 40.As such, there is no evidence for the $X$-linked inheritance of MLS given the described neurological traits in the ancestors of Henry VIII.

Given the above, it is more likely that if Catherine de Valois did carry a genetic predisposition for mental illness, it was autosomal. This however, does not refute the possibility that a mutation in the McLeod gene arose spontaneously, 'de novo', in Henry the VIII. Unfortunately there is no widely accepted common diagnosis for these four kings, no available DNA studies and not even a universally accepted diagnosis for any one of them.

\section{CONCLUSION}

Jacquetta Woodville may well have carried the Kell positive gene. Whitley and Kramer's first hypothesis may be correct. Katherine of Aragon's initial miscarriages and perinatal deaths, followed by a successful fifth pregnancy are not typical of Kell antigen sensitivity, but could be explained by Mary being the only child of Henry and Katherine's union to inherit a Kell negative $k$ gene from Henry. Alloimmunisation with Kell antibodies can occur in the first pregnancy; hence the normal first pregnancy concept in Whitley's hypothesis is partially correct.

McLeod's syndrome is associated with only phenotypic inactivation of Kell antigen system; hence the two conditions of MLS and unsuccessful pregnancies in the female partner of a Kell positive male can coexist in an individual, unless skewed $\mathrm{X}$-chromosome inactivation occurs. The possibility that Henry had both problems causing his mental degeneration to become a murderous tyrant cannot be substantiated further without DNA analysis. However, the historical records do not support the suggestion of an MLS pedigree.

Genetic studies of Henry's remains, as have recently been performed on Richard III, could clarify the situation and terminate the debate. Such testing would require his disinterment and approval for this seems unlikely. 


\section{REFERENCES}

I Whitley C, Kramer K. A new explanation for the reproductive woes and midlife decline of Henry VIII. The Historical Journal 20 I0; 53:827-48. http://dx.doi.org//0.10I7/S00 I8246XI0000452

2 Keynes M. The personality and health of King Henry VIII (I49II547). J Med Biogr 2005; 13:I74-83. http://dx.doi.org//0.1258/j. imb.2005.05-20

3 Holinshed's Chronicles of England, Scotland, and Ireland [Internet]. London:J Johnson; I807. p. 3 I 4 [cited 2013 Oct 3 I].Available from: www.english.ox.ac.uk/holinshed/texts

4 www.englishhistory.net/tudor/facts [Internet]. Total population in Tudor England [cited 2013 Nov 5]. Available from: http://www. englishhistory.net/tudor/facts

5 Amnesty International. The death penalty in 2012 [Internet]. London: Amnesty International; 2012 [cited 2013 Oct 22]. Available from: http://www.amnesty.org/en/death-penalty/death-sentences-andexecutions-in-20I2

6 Chalmers CR, Chaloner JE. 500 years later: Henry VIII, leg ulcers and the course of history. J R Soc Med 2009; 102: 5 I4-7. http:// dx.doi.org// 0.1258/jrsm.2009.090286

7 Barret N. King Henry the eighth. Ann R Coll Surg Engl 1973; 52 216-33.

8 Shrewsbury JF. Henry VIII: a medical study.] Hist Med Allied Sci 1952; 7: I4I-85. http://dx.doi.org/I0.1093/jhmas/VII.2.I4I

9 Stride P. King Edward IV, a type II diabetic? The Ricardian Register 201 I; 42: I4-9.

10 Stride P. Was syphilis originally introduced into the United Kingdom by the mercenary army of Perkin Warbeck's Scottish campaign? The Ricardian 2010; 4:36-8.

II Hesner MJ, Curtis BR. Prenatal genotyping for identification of fetuses at risk for immune cytopenic disorders. In: Coleman WB, Tsongalis GJ (editors). Molecular diagnostics: for the clinical laboratorian New York: Humana Press; 2006. p. 329. http://dx.doi.org/I0.1385/I 59259-928-I:329

12 Musclow CE, Abbott D, Tobin SM. Multiple antibody formation in a primagravida: anti-D, anti-C, anti-kpb. Obstet Gynecol 1982 59:10S-2S

I3 Mckenna DS, Nagaraja HN, O'Shaughnessy R. Management of pregnancies complicated by anti-Kell isoimmunization. Obstet Gynecol 1999; 93:667-73. http://dx.doi.org/10.1016/S0029. 7844(98)0049I-8

I4 van Wamelen DJ, Klumper FJ, de Haas $M$ et al. Obstetric history and antibody titer in estimating severity of Kell alloimmunization in pregnancy. Obstet Gynecol 2007; 109:1093-8. http://dx.doi org/I0.1097/0I.AOG.0000260957.77090.4e

I5 Falkus G. The life and times of Edward IV. London:Weidenfeld and Nicolson; I98I. p. 87

16 Kendall PM. Richard the third. London:Allen and Unwin; 1955.

17 Hicks M. Richard III: the man behind the myth. London: Collins and Brown; 1991. p. 83

I8 Ross C. Edward IV. Los Angeles: University of California Press; 1974

19 Rogers K. Blood physiology and circulation. New York: Britannica Publishing; 201 I. p. 103.
20 Valko PO, Hänggi J, Meyer $M$ et al. Evolution of striatal degeneration in McLeod syndrome. Eur J Neurol 2010; 17:612-8. http://dx.doi. org/I0. I I I I/j. I468-I33I.2009.02872.x

2I Watkins CE, Litchfield J, Song E et al. Chronic granulomatous disease, the McLeod phenotype and the contiguous gene deletion syndrome - a review. Clin Mol Allergy 20I I; 9:13. http://dx.doi. org/I0.II86/I476-796I-9-I3

22 Singleton BK, Green CA, Renaud $S$ et al. McLeod syndrome resulting from a novel XK mutation. Br J Haematol 2003; $122: 682$ 5. http://dx.doi.org/I0.1046/j.I365-2 I4I.2003.04474.x

23 Zeman A, Daniels G, Tilley L et al. McLeod syndrome: life-long neuropsychiatric disorder due to a novel mutation of the $\mathrm{XK}$ gene. Psychiatr Genet 2005; 15:29l-3. http://dx.doi.org/I0.1097/ 0004|444-2005I2000-000I2

24 Supple S, lland HJ, Barnett $\mathrm{MH}$ et al.A spontaneous novel XK gene mutation in a patient with McLeod syndrome. Br J Haematol 200 I; | I5:369-72. http://dx.doi.org/ 0.1046/j.|365-2 |4I.200I.03 I2I.x

25 Walker RH, Danek A, Uttner I et al. McLeod phenotype without the McLeod syndrome. Transfusion 2007; 47:299-305.

26 Kormoczi G, Scharberg EA, Gassner C. A novel KEL*I, 3 allele with weak Kell antigen expression confirming the cis-modifier effect of KEL3. Transfusion 2009; 49:733-9. http://dx.doi. org/I0.IIII/j.I537-2995.2008.0203I.x

27 Jung $\mathrm{HH}$, Danek A, Frey BM. McLeod syndrome: a neurohaematological disorder. Vox Sanguinis 2007; 93: II2-2I. http://dx.doi.org/I0.I I I I/j.|1423-04/0.2007.00949.x

28 Orstavik KH, Orstavik RE, Schwartz M. Skewed X chromosome inactivation in a female with haemophilia $B$ and in her non-carrier daughter: a genetic influence on $\mathrm{X}$ chromosome inactivation? J Med Genet 1999; 36:865-6.

29 Dubielecka PM, Hwynn N, Sengun C et al. Two McLeod patients with novel mutations in XK. J Neuro Sci 201I; 305:160-4. http:// dx.doi.org/I0.1016/j.jns.201 I.02.028

30 Ho MF, Chalmers RM, Davis MB et al. A novel point mutation in the McLeod syndrome gene in neuroacanthocytosis. Ann Neurol 1996; 39: 672-5. http://dx.doi.org//0.1002/ana.4I03905/8

31 Cox TM, Jack N, Lofthouse S et al. George III and porphyria: an elemental hypothesis and investigation. Lancet 2005; 366:332-5. http://dx.doi.org//0.1016/S0I40-6736(05)6699I-7

32 Peters T, Garrard P. Computer-based diagnosis of illness in historical persons J R Coll Physicians Edinb 2013; 43:161-8. http:// dx.doi.org/I0.4997/JRCPE.20I3.2I5

33 Rohl JC, Warren M, Hunt D. Purple secret: genes, 'madness' and the royal houses of Europe. London: Bantam; 1998.

34 Hift RJ, Peters TJ, Meissner P.A review of the clinical presentation, natural history and inheritance of variegate porphyria: its implausibility as the source of the 'Royal Malady'. J Clin Pathol 2012; 65:200-5.

35 Bark N. Did schizophrenia change the course of English history? The mental illness of Henry VI. Med Hypotheses 2002; 59:4I6-2I. 